\title{
Ten Rules for Public Economic Policy
}

\author{
Yew-Kwang NG
}

\author{
2017
}

EGC Report No: 2017/03

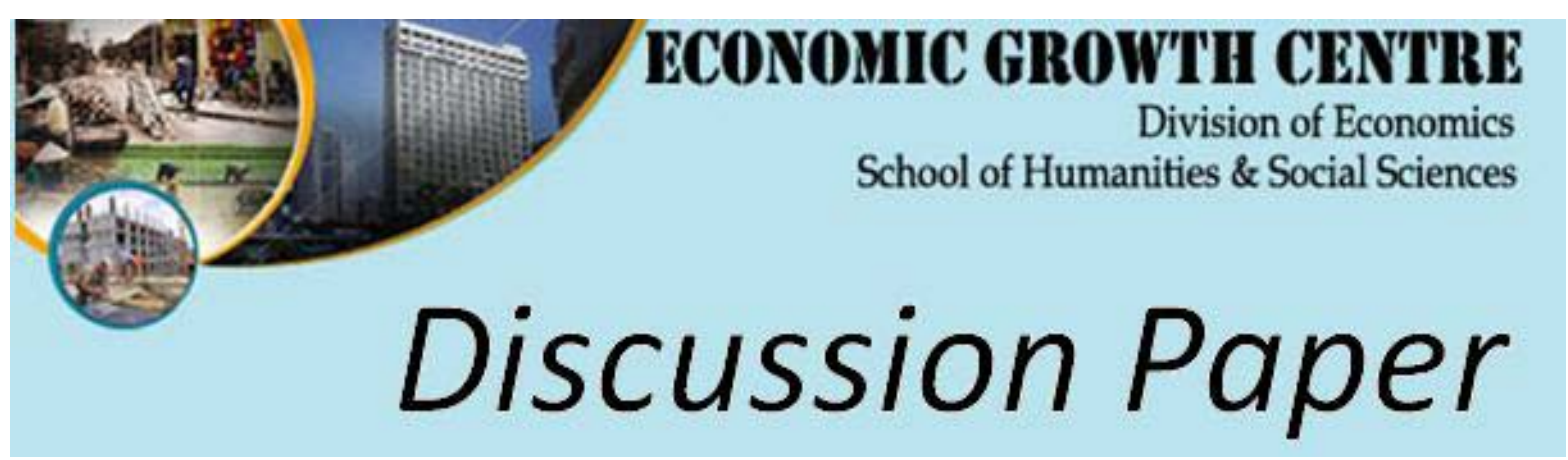


The author(s) bear sole responsibility for this paper.

Views expressed in this paper are those of the author(s) and not necessarily those of the Economic Growth Centre, NTU. 


\title{
Ten Rules for Public Economic Policy
}

\author{
Yew-Kwang Ng \\ Division of Economics \\ Nanyang Technological University, Singapore \\ ykng@ntu.edu.sg
}

\begin{abstract}
This paper discusses ten simple rules for the formulation of public economic policies efficiently, using both old wisdom and recent results. The ten rules are: Using the Invisible Hand; Provision of Essential Public Goods; Reducing Excessive Inequalities Efficiently; Adopt Free Trade and Eliminate Administrative and Collusive Monopolies; Provide Useful Information and Regulation; Raise Taxes Efficiently; Mitigate against Excessive Market Fluctuations; Undertake Public Projects Efficiently; Soft Paternalism; Happiness-Oriented Objectives. Justifications and qualifications are discussed.
\end{abstract}

Keywords: Economic policy; ten rules; ten commandments; efficiency; public economics.

JEL codes: H00-Public Economics, General.

\section{Funding Acknowledgement}

This work was supported by Nanyang Technological University, Grant: M4081118.100.601001. 
Public economic policies affect the economy and the livelihood of people enormously. It is important to pursue these policies appropriately. Some simple rules may help. I did not think of writing these rules. However, Prof. Yusen Kwoh, Director of the Jinhe Center for Economic Research of Xi'an Jiaotong University suggested that I should write the 'ten commandments' for economic policy. I do not dare to call them 'commandments' and hence use 'rules' instead. [I have invited Prof. Kwoh to join in the authorship of this paper but he politely declined.] I will first list my proposed ten rules before discussing their details and justifications. Comments and discussions are welcome. In contrast to the 'Ten commandments for policy economists' by Leman \& Nelson (1981) which focus more on 'policymaking ... skills', we focus more on the content or principles of good economic policy. Hopefully, this may provide some broad overall guides for economic policy formulation and public economics analysis. [For some other economics-related ten commandments, see, e.g. Buiter 2003, Blanchard \& Cottarelli 2010, O'Donnell 2012.] Our discussion is largely based on a welfarist framework that what is socially important is ultimately social welfare which should be a function of individual welfares. For those (like the Kantians) believing in deontic rules over-and-above welfare, they may have additional qualifications or constraints. (See Sen 2010 for an analysis of justice taking account of welfarist considerations and beyond, and Kaplow \& Shavell 2002 on the importance of welfare for fairness.)

\section{TEN RULES OF ECONOMIC POLICY}

1. Invisible Hand: Let the market coordinate economic activities except where there are significant market failures.

2. Provision of Essential Public Goods: Provide essential public goods including: Law and order, including the protection of personal freedom and safety, property rights; essential environmental protection; infrastructures like transport and communication.

3. Reducing Excessive Inequalities Efficiently: Promote equality in income and wealth distribution, including possibly taxing the rich more to help the poor, but not excessively and follow the principle of 'a dollar is a dollar' (efficiency rules supreme in specific policies) where relevant. 
4. Adopt Free Trade and Eliminate Administrative and Collusive Monopolies: Distinguish between monopolistic power created by innovation and that created by collusion and regulation. Adopt free domestic and international trade and investment to promote competition.

5. Provide Useful Information and Regulation: Food safety, financial regulation.

6. Raise Taxes Efficiently: Give priority to corrective taxes on pollution and burden-free taxes on diamond goods.

7. Mitigate against Excessive Market Fluctuations: Provide sufficient but not excessive liquidity to maintain low inflation and avoid depressions.

8. Undertake Public Projects Efficiently: Major public projects with unclear benefit-to-cost ratios have to pass through cost-benefit tests done by professional economists plus relevant experts.

9. Soft Paternalism: Undertake certain soft measures for welfare improvement addressing imperfect information and imperfect rationality.

10. Happiness-Oriented Objectives: Going beyond GDP to more happiness-oriented objectives like the environmentally responsible happy nation index.

\section{EXPLAINING/JUSTIFYING THE TEN RULES}

Rule 1: Invisible Hand: Let the market coordinate economic activities unless there are significant market failures.

The market functions properly within the institutional framework of law and order, including the protection of property rights, under certain conditions. All economics students know of Adam Smith's invisible hand. Not many know that around 18.5 centuries before the Wealth of Nations (1776), Sima Qian (formerly known as Ssu-ma Chien; 司马迁) expounded the same principle (though certainly far from Smith’s level of sophistication and details): 'like water falling downward’ by itself in his Historical Records (《史记》, <货殖列传>). In its modern incarnation, the principle of the invisible hand is formulated as the first theorem in welfare economics. This theorem states that a perfectly competitive equilibrium of a market economy is perfectly efficient (Pareto optimal) in the absence of external effects and relevant imperfect information. (Economists including Kenneth Arrow, Gérard Debreu, Abba Lerner, Harold Hotelling were involved in the demonstration of the first welfare theorem; for exposition, see 
Mas-Colell et al. 1995, ch.16; Ng 2004, ch. 2; Ng 2015.) This suggests the following possible prima facie grounds for government intervention/activities: Correcting serious inequalities (since the theorem only relates to pure Pareto efficiency); dismantling administrative and collusive monopolies (since the condition of perfect competition is needed for perfect efficiency); controlling environmental disruption (an important form of external costs); providing essential public goods; providing relevant information and certain safety regulations, as discussed in other rules below. On the role of property rights in economic development, see Besley \& Ghatak (2010) for a survey and on institutions more generally, see Ogilvie \& Carus (2014).

Since perfect competition rules out increasing returns, the presence of increasing returns due to the existence of large fixed costs (related to indivisibilities) and/or the economies of specialization from the division of labour at the economy level may lead to some possible reasons for the failure of the market to achieve perfect efficiency by itself. However, our understanding of the complications created by these factors is not sufficient to provide a clear guide for possible intervention. Thus, this has not been included within the ten rules, but readers are referred to some analyses including Arthur (1994), Yang \& Ng (1993), Ng (2009); see also the related issues of complexity and evolutionary economics (e.g. Arthur 2014; Colander \& Kupers 2014; reviewed by Kirman 2016; Miller 2015).

Rule 2: Provision of Essential Public Goods: Provide essential public goods including: Law and order, including the protection of personal freedom and safety, property rights; essential environmental protection; infrastructures like transport and communication.

For the market to function, not to mention achieving Pareto efficiency as discussed in Rule 1 above, the protection of personal freedom, safety, and property rights is essential. Clearly, if most of what one produces will be stolen without compensation, not many will have incentives to produce to begin with. Thus, the provision of law and order is essential. The provision of other public goods may also be justified. A public good has the characteristics of being non-rivalrous in consumption; its provision to any consumer entails possible costless consumption by others. This usually gives rise to free-riders, making private provision difficult, especially to achieve efficiency without denying potential consumers, and especially for those public goods that are also costly to exclude non-paying consumers. The provision of public goods by the government 
raises the question whether they may be provided efficiently and whether their provision justifies the costs involved.

For a private good, a consumer reveals her preference for it, at least at the margin, by being willing to buy a certain amount at a certain price. For a public good provided by the government and available to all, how could we be sure that the good has high enough value (aggregated over all individuals in the relevant society) for money. For very essential public goods, their total values may clearly be larger than their total costs of provision. Still, we want to be reasonably confident that their marginal amounts are worth providing as well. If we ask people for their valuation of public goods, they may exaggerate if they do not have to pay; they may seriously understate if they have to pay. It was thus thought that, given self-interested individuals, this is an intrinsically unsolvable problem. Thus, the discovery of an incentivecompatible mechanism for preference revelation for public goods was a very important advance in economic analysis (Clarke 1980, Groves 1973, Vickrey 1961; See Sec. 8.3 of Ng 2004 for a review). There is much scope for using this mechanism in practice despite some difficulties.

Conceptually, the optimal amount of spending on public goods, either on a specific item or the total amount of public spending, is originally taken as the Samuelsonian rule of the equation of aggregate (over all individuals concerned) marginal valuation with the marginal cost of provision (Samuelson 1954). Next came the well-known (among economists) recognition (original recognition dating back at least to Pigou 1928) that since 'it becomes more costly to obtain public goods when taxation imposes distortions, normally this will imply that the efficient level of public goods is smaller than it would have been with nondistortionary taxation' (Stiglitz 1988, p.140). If we take the average estimate of $30 \%$ of the distortionary costs as a proportion of the amount of revenue raised, the benefit-to-cost ratio of a public project has to exceed 1.3 instead of just one, for it to be considered worth providing.

Thirdly and unexpectedly (and still not widely known) came the argument by Kaplow (1996). He argues that public goods can be financed without additional distortion by using an adjustment to the income tax that offsets the benefits of the public good. The 'preexisting income tax schedule is adjusted so that, at each income level, the tax change just offsets the benefits from the public good. By construction, an individual's net reward from any level of work effort will be unaltered; any reduction in disposable income due to the tax adjustment is balanced by the benefits from the public good. Because an individual's after-tax utility as a 
function of his work effort will thus be unchanged, his choice of work effort - and utility level will also be unaffected' (Kaplow 1996, p.514).

Though some complicated factors are involved, Ng (2000) largely supports Kaplow. (See also Jacobs 2013, Burns \& Ziliak 2017.) Consider a specific example of the public good of providing law and order. With no public goods and no taxation, you keep the full amount of the additional \$100 earned at the margin. If you have to pay 30\% income tax, your incentive to work for just $\$ 70$ seems less. However, as income taxes are not thrown into the ocean but used to provide law and order, you may have higher incentives to earn the protected $\$ 70$ than the unprotected \$100. Apart from supporting Kaplow, $\mathrm{Ng}$ goes further in arguing for reducing the required benefit-to-cost ratio (for public projects) not only from 1.3 back to one (Kaplow's position), but to well below one, because:

1. The orthodox (pre-Kaplow) position of the 30\% distortionary costs of taxation is based on the assumption that the pre-tax position is socially optimal to begin with. Since most forms of production and consumption involve significant environmental disruption costs that have not been adequately taken account of, the $30 \%$ or so income and/or consumption taxes are largely corrective than distortive, justifying the reduction of the required benefit-to-cost ratio from one to about 0.7 .

2. Due to the widespread prevalence of relative-income/consumption effects, the increase in income/consumption of an individual actually imposes external costs on others, justifying a further reduction of the required benefit-to-cost ratio from 0.7 to about 0.5. (On the importance of relative competition even among people of low incomes, see Knight et al. 2009, Guillen-Royo 2011, Linssen et al. 2011. Blanchflower \& Oswald 2004 argue that relative competition alone justify a tax rate of at least 33.3\%. On the distinction of physical vs. psychological external effects, see Mueller 2009, pp. 241-3).

3. Most happiness studies suggest that, after the survival and minimum comfort levels, further increases in private income/consumption have little if any positive effects in increasing happiness (e.g. Diener et al. 2010, Ng 2013). Since happiness is and income is not the ultimate objective, for items of public spending that could really increase happiness, they may well be worthwhile even with high money costs, since their happiness costs are very low, justifying a further reduction of the required benefit-to-cost ratio from 0.5 to perhaps 0.3 or lower. Of course, if the public spending is on something bad like financing an unjust war, 
it could be worse than nothing and cannot pass the benefit-to-cost ratio of even just 0.01 , as its benefits are negative.

In other words, the bias of most economists against public spending ('big society, small government') is based on the asymmetric fuller recognition of the costs and inefficiencies of public spending but the disregard or inadequate recognition of those of private consumption, especially in terms of environmental disruption, relative competition, and over emphasis on material consumption (Ng 2000; Ng 2013). However, not all economists are biased against public spending. For example, Besley \& Persson (2013) find the central question in taxation and development is: "how does a government go from raising around 10\% of GDP in taxes to raising around $40 \% "$ ?

\section{Rule 3: Reducing Excessive Inequalities Efficiently}

Even if the economy functions perfectly efficiently as the idea of the invisible hand and the first theorem in welfare economics state, it may involve a high and unacceptable degree of inequality in the distribution of income and wealth. Thus, the reduction of excessive inequality is a potential justification for government intervention. However, it depends on whether the gain in equality justifies the various costs involved, as discussed below.

Inequality may arises from a number of reasons, including

A. Differences in inborn earning abilities, e.g. $\mathrm{J}$ has a sexy voice attracting thousands of fans each paying hundreds of dollars to listen to J singing; when K sings, people run away.

B. Differences in inherited wealth; but this has to be traced back to the previous generations.

C. Differences in preference or actual choice especially regarding work vs. leisure (those preferring leisure have less monetary incomes but not full income inclusive of leisure), saving for the future vs. current consumption, willingness to bear risks especially in earning incomes.

D. Differences in preference or actual choice regarding acceptable or dubious (e.g. with substantial costs on others) forms of earning.

E. Differences in social, legal, or situational conditions affecting one's abilities in earning, including possible discrimination, connection to people of influence, etc.

F. Differences in luck. 
Most people find inequalities due to factor $\mathrm{C}$ more tolerable and arguably not real inequalities, and those from factors D and E much less tolerable. Factors A, B, and F may be regarded as similar since they may be regarded as different forms of generalized luck.

Apart from considerations of desert, an important reason justifying the importance of equality is that incomes of the poor meets more important needs than incomes of the rich, at the margin. Increasing equality without causing too much disincentive effects may thus increase aggregate utility/welfare. In contrast to the traditional concern with the big trade-off between equality and efficiency (e.g. Meade 1964, Mirrlees 1971, Okun 1975/2015), more recent studies (e.g. Berg \& Ostry 2011, Milanović 2011, Stiglitz 2012, Mokyr 2014) emphasize possible complementarities between them. Excessive inequality is usually not only bad in itself but also not good for growth and efficiency due to a number of factors, including lower social harmony, higher crime rates, less flourishing of ideas from the lower groups, etc. Also, the shift in importance from physical to human capital is also relevant: when physical capital was important, inequality increased growth by increasing savings and hence capital accumulation; when human capital is more important, equality increases the achievement of widespread education. In addition, '...economic historians such as Lindert (2004, 2009) ... have shown the complex, but on the whole favorable, effect of the Welfare State on economic performance to the point where the full economic benefits and costs may have been roughly equal, making the Welfare State a “free lunch”' (Mokyr 2014, p.191). Also, 'Economic historians have shown (Solar 1995; Greif and Iyigun 2013) that the net effect of the Poor Law was probably to foster technological progress, because it weakened the resolve of the inevitable losers to resist it and thus reduced social unrest' (Mokyr 2014, p.192). These suggest that more equality-improving measures including welfare spending may be desirable.

To increase equality efficiently, one important aspect is that, at least as a rule, it is more efficient to focus on the equality in general income or wealth. A person is poor if she has low purchasing power in general, not if she spends less on a particular item. Thus, we should try to increase equality in general purchasing power rather than to pursue equality in specific measures. In specific issues, we should pursue efficiency (treating a dollar as a dollar whether for the rich or the poor). For any alternative that violates this efficiency-supremacy policy in specific issues, we may get rid of the efficiency-violation and make the general equality-promoting policy (including general tax-transfer) more progressive, with the two changes offsetting to each other, 
making all income groups equally well-off. Since incentives to earn incomes should be a function of overall effects inclusive of effects of equality-pursuit in specific policies, our alternative that achieve the same degree in the distribution of real income (utility) will also have the same degree of incentives. However, it has less additional distortion effects, making the government able to collect more taxes and/or has to give less subsidies, while making all groups equally well-off. This gain in revenue may be distributed to make all groups better off, achieving a quasi-Pareto social improvement (Ng 1984). Only a quasi-Pareto improvement is assured, as some people may be made worse off. However, within any income group, those made worse off could be more than compensated by the gain of those make better off. Since they belong to exactly the same income group, the absence of actual compensation is not a real concern. (For other discussion of how to reduce inequality, see, e.g. Stiglitz 2015.)

\section{Rule 4: Adopt Free Trade and Eliminate Administrative and Collusive Monopolies}

Together with other conditions, the first welfare theorem only ensures efficiency under the condition of perfect competition. Thus, if there is monopolistic power, efficiency may suffer. However, it is very important to distinguish between monopolistic power created by innovation and that created by collusion and regulation. The patent law allowing a certain period of exclusive property rights makes sense as it provides some incentives for inventors and innovators even though it confers some monopolistic power. The progress and benefits to consumers created more than offset temporary monopolistic restriction of output. On the other hand, monopolistic power created by collusion (such as a cartel) does not confer benefits to consumers and thus should not be allowed. In the absence of legal sanction, a cartel is usually difficult to enforce. [Even the world's most well-known cartel, OPEC, may not ever have been a functioning cartel, if Cairns and Calfucura (2012) are right; see also Colgan 2014, Baumeister \& Killian 2016.] Thus, the elimination of the government role in creating administrative monopolies is very important. ${ }^{1}$ Also, the adoption of free domestic and international trade and investment is important in promoting competition. Going beyond the static framework of most welfare analysis to include technological, institutional, and policy changes, this is particularly crucial for developing countries in closing the gap with more advanced economies. This partly explains the China miracle in the past 3-4 decades in having close to double-digit annual growth rates.

\footnotetext{
${ }^{1}$ Market imperfection also has income distributional implications; see Yilmaz (2016).
} 


\section{Rule 5: Provide Useful Information and Regulation}

The assumption of perfect information (even if confined to only relevant information) is of course unrealistic. Most if not all consumers do not know much regarding whether there are ingredients in food that may be harmful, especially in the long term (instead of making you going to the toilet in less than half an hour). Thus, regulations like food safety are very important. Though this may sit less comfortably with the simple textbook assumptions, it is more consistent with recent studies of information, behavioural, and experimental economics. Imperfect information (often the asymmetric aspect, where one side of the market has less info than the other, may also be relevant), imperfect rationality, herding behavior, financial interconnectedness, etc. may also lead to some inefficiencies that the government may or may not be able to improve upon.

Our understanding in this complicated area is far from adequate. For one thing, the financial markets often behave counter to the prediction of economic analysis of real factors. For example, on 18 September 2013, the Federal Reserve (central bank) of the U.S. announced that the economic recovery was too fragile to cut back on its massive \$85billionn-a-month government bond purchase stimulus program. The U.S. share market responded to this by hitting a record high. This was like a patient, after learning from his medical doctor that he had not recovered enough to decrease the daily dosage of medication, went out to celebrate the 'good' news!

Though we have some economic analysis incorporating the financial sector (e.g. Brunnermeier \& Sannikov 2014), much more is needed. A recent discussion (Ng 2014) of the importance of finance mainly emphasizes one aspect of the problem, how the importance of monopolistic competition makes a decrease in nominal aggregate demand (as may be triggered by a financial crisis) possibly leading to unemployment, contrary to the traditional neutrality of money. Obviously, many more issues are involved and these are largely un-resolved. Many more studies, both conceptual and empirical, are needed.

\section{Rule 6: Raise Taxes Efficiently}

Government spending (see Rule 2 above) requires government revenue. Though some governments rely on the sale of their assets including land, usually the most important sources of 
government revenues are various forms of taxation, including income and consumption taxes, import tariffs, taxes on property transaction and ownership. Raising taxes is usually needed but it should be done efficiently. Most discussion of optimal taxation follows the Ramsey tradition of trying to minimize the excess burden or distortionary costs of taxation. Though a proper analysis should take the whole economy (all goods, taken to subsume services) into account including the consumption and the production sides, the principal idea can be seen by the textbook supplydemand analysis of the excess burden of the taxation of a single good. For any given amount of tax revenue raised, the more elastic the demand and supply, the larger is the amount of distortion and the amount of excess burden. The idea of optimal taxation is to take account of this and, for any given amount of total revenue needed, designed a tax-rate structure over all goods to minimize the total distortionary costs. Though this principle is well-taken in the given framework, actually no distortionary costs of taxation need be incurred at all. The production and consumption of most goods impose both significant environmental disruption and relativecompetition costs on others. Estimates of just the relative-competition effects alone justify a taxation rate of $30 \%$ or higher. Adding the significant effects of congestion, pollution, and environmental disruption in general probably requires corrective tax rates higher than needed for most countries. Ideally, apart from a general income (with progressivity to account for Rule 2 above) and/or consumption tax rate of 20-30\%, much higher taxes should be imposed on production with more serious pollution and consumption with more serious conspicuous effects. Ideally, a Pigovian tax on an external cost should be in accordance to the marginal damages imposed. However, such damages, especially for the global warming problem that affects the whole world and for centuries to come, are very difficult to estimate. However, Ng (2004) argue that, for most cases where some abatement spending is desirable, taxes imposed should be at least equal to the marginal costs of abatement investment. This is much easier to estimate than the marginal damages. Moreover, the amount of revenue collected will be larger than the optimal amount of abatement investment, thus solving also the financing problem for this investment. (See also Barrios et al. 2013 on the efficiency of green taxes and Kaplow 2008 on more general issues of taxation and public economics.)

In addition to corrective taxes discussed above, there is another type of goods with negative excess burden. Goods valued for their values rather than their intrinsic consumption effects are called diamond goods. A tax on a pure diamond good of $\$ 100 \mathrm{~m}$ imposed not only no 
excess burden of \$30m, it imposes no burden at all, as shown in $\mathrm{Ng}$ (1987). The percentage of negative burden is $100 \%$. Though not many goods are pure diamond goods, there are many mixed diamond goods (valued both for their values and their intrinsic consumption effects) that still provides sources for revenue with negative excess burdens.

As the amount of revenue raised from corrective taxation and taxes on diamond goods is likely to meet government spending in most cases, no additional taxes are needed purely for raising revenue. (See the discussion of Rule 2 above.) Then, we may forget about Ramsey taxation in practice, leaving it for graduate teaching as an interesting analytical exercise. This is so since corrective taxes generate efficiency gains rather than impose distortionary costs. Moreover, the amounts of efficiency gains are maximized by imposing taxes in accordance to the marginal damages (or the marginal costs of abatement) involved irrespective of the relevant demand and supply elasticities.

\section{Rule 7: Mitigate Against Excessive Market Fluctuations}

Just like the performance at the microeconomic level, the macroeconomy also typically performs well but imperfectly. In a growing and changing economy, transfers of resources from the declining to the growing sectors are needed and some fluctuations are unavoidable. However, partly due to the inter-relatedness and herding behaviour mentioned above (see Rule 5), the economy sometimes fluctuates excessively both in price and real output levels, and both at the micro and macro levels. For the macro level, the Great Depression of 1929-1933 imposed heavy tolls. Though economists differ on the causes of the depression, there is some consensus that the U.S. Federal Reserve (central bank) should have cut short the monetary deflation and banking collapse to prevent the huge decline in aggregate demand. In contrast, economies in the world fared much better during the Great Recession from around 2008. Though problems have been created by the frantic easy money policies (including the various rounds of quantitative easing in the U.S., the RMB $\$ 4$ trillion stimulus program of China in 2009, and the negative interest rates of Japan and Europe recently), at least drastic collapses in employment and aggregate output levels at the scale of 1929 have been avoided.

Apart from fluctuations in output and employment levels, we may also have excessive

inflation in the general price level. While a low rate of inflation of around $2-3 \%$ annually may 
facilitate structural adjustments, excessive inflations especially hyper-inflations are usually very detrimental to the economy.

Excessive fluctuations also occur at the micro levels (though also connected to the macro fluctuation), e.g. after hitting its historical record of 11,793 on 20 May 2008, the Baltic Dry Index dropped to 290 on 11 February 2016, losing 97.54\% (now back to 670 on 21 April 2016, an increase of more than $131 \%$ in 70 days). However, it is more problematic as to the needs, feasibility, and desirability of avoiding fluctuations at the micro level. This again points to our inadequate knowledge and the scope for further research.

\section{Rule 8: Undertake Public Projects Efficiently}

In contrast to overall public spending discussed in Rule 2 above, this rule relates to specific projects. Except for cases of either obvious necessity and cases of small amounts of funding involved, large public projects should normally undergo an adequate cost-benefit analysis to avoid wastes of white elephants. However, if we want to maximize the welfare instead of the utility (representing preference) levels of individuals, adjustments to take account of factors discussed under Rule 2 (see Ng 2003 for more details) are needed.

\section{Rule 9: Soft Paternalism}

Informational, experimental and behavioural economics, psychological studies (e.g. Kahneman 2011) and the obvious presence of herding behaviour and excessive fluctuations discussed above suggest both imperfect rationality and imperfect information. This makes certain government intervention possibly desirable or welfare-improving. However, excessive paternalism may be counter-productive both in its effects and its procedure, including the long-term implications on freedom and welfare. Thus, a good compromise is the use of soft paternalism that attempts to offset problematical individual choices due to imperfect information and rationality, without interfering too much with individual liberty. One successful soft paternalistic policy is the 'save more tomorrow' where the right conservatives and the left liberals of the U.S. combined force to promote it. Many people resist saving more as reducing consumption now is seen as painful. However, many signed up to save more in the future when their pays would increase next. Saving parts of future pay rises is seen as much less difficult (Thaler \& Sunstein 2009). More 
economic analysis with imperfect rationality including the policy implications is being undertaken, e.g. Gerritsen (2016).

Another soft paternalistic policy is to require the better alternative designated as the default option, without denying the liberty of people to change it to some other option at request. For example, since there is a consensus among health experts that whole-meal bread is healthier than white bread, making canteens, especially those in schools, observe selling the default of whole-meal bread unless buyers ask for white bread makes sense. I shifted from white to wholemeal bread while doing my PhD. Within a week or so after the shift, I was tempted many times to shift back as the whole-meal one is tougher to chew. But I persisted for health reasons. Then I got used to it. A few months later, I once could not find whole-meal bread and had to buy a white one instead. After eating that, I said, 'How could this stuff be edible; tasting like flour!' After getting used to the chewy whole-meal bread, I actually prefer it even on taste alone. Not shifting to whole-meal is probably due either to ignorance or irrationality. Young children should particularly be trained to eat healthily. Another desirable rule is that organ donation after death should be the default unless the person signed up to deny donation. Most countries have the opposite default of non-donation which is clearly an inferior arrangement ( $\mathrm{Ng}$, forthcoming).

\section{Rule 10: Happiness-Oriented Objectives}

Economic production and consumption are not our ultimate objectives. There have been various attempts to go beyond GDP or GNP, including the Human Development Reports (related to the studies of Mahbub ul Haq and Amartya Sen; see United Nations Development Programme 2015), the 'Sarkozy report' by Stiglitz et al. (2009), and many others. Since what is of ultimate value is welfare or happiness (Diener, et al. 2010; Ng 1990; Ng 2013) and our survival is threatened by possible global extinction due to environmental disruption, a happiness-based measure taking account of environmental protection may be a good national success indicator to complement, if not replace, GDP. For such an environmentally responsible happy nation index, see Ng (2008). This takes positive account of long and (net) happy life-years and negative account of environmental costs imposed on others and the future. There is also increasing use of happiness info/data to help assist economic analysis and policy (e.g. Andersen, et al. 2016, Blanchflower, et al. 2014, Levinson 2012). 


\section{CONCLUDING REMARKS}

The ten rules above may serve some useful purposes. They covers some important issues, Though focussing on economic policy, they are not confined to purely economic factors; a wider perspective is adopted. However, they are certainly not exhaustive and may reflect my personal bias and limitations. Some limitations may be our imperfect knowledge, pointing to the need for further research. In particular, the following deficiencies, as also remarked above, may be emphasized.

- The presence of increasing returns at the firm level or the economy level and other issues as discussed in evolutionary economics and complexity studies may make the first welfare theorem not applicable, creating some complications. However, our understanding of the implications of this for appropriate public policy is not sufficient to provide some simple rules.

- Information, behavioural and experimental economics are still being actively studied. Though some insights are available (Rule 9), much more studies are needed before some more useful simple rules may be formulated.

- Similarly, the relevance of financial, institutional and other factors especially in a dynamic framework incorporating innovation and policy changes, are also not well understood; more studies are needed.

One may argue that the consideration of these factors may make some of the simple rules above not really applicable. For example, the presence of increasing returns may make free trade in specific cases not welfare-improving. The theory of second best (Lipsey \& Lancaster 1956) or its generalization suggests that we have then to take all the complicated relationships into account to assess the appropriate policies or the efficiency implications. However, before we have sufficient information to know how to depart from the simple first-first rules (including the ones suggested above), we will probably maximize expected efficiency/welfare by sticking to these simple rules, upon the argument of the third best (Ng 1977) or its generalization. (See also the debate between Lipsey and Ng, 2017.) For example, despite his new trade theory which may justify selective interventions, Krugman (1987) has the wisdom for sticking to free trade. 
More importantly, even for some cases where some sophisticated measures may be desirable, it is highly unlikely that, in practice, a government, even if benevolent, will be able to tackle the complicated cases well enough to justify the administrative and informational costs, and possible indirect costs of a meddling or interventionist policy. If we take into account issues of rent-seeking and sectional interests, the feasibility and desirability of sophisticated measures beyond simple rules become even more questionable. Though these factors also make even the observance of simple rules difficult, it is relatively easier to advocate and pressure the rough observance of simple rules, than sophisticated ones which are more liable to be twisted to serve sectional interests. Thus, unless amply justified, like the need for strong environmental protection and food safety as discussed above, it is usually desirable to be conservative. The conservative policy of 'small government and big society' has some validity in this sense.

\section{References}

ANDERSON, M.L., F. LU, Y. ZHANG, J. YANG, P. QIN, (2016). Superstitions, street traffic, and subjective well-being, Journal of Public Economics, 142: 1-10.

ARTHUR, W. Brian (1994). Increasing Returns and Path Dependence in the Economy. Ann Arbor: University of Michigan Press.

ARTHUR, W. Brian (2014). Complexity and the Economy, Oxford University Press.

BARRIOS, S., PYCROFT, J., \& SAVEYN, B. (2013). The marginal cost of public funds in the EU: the case of labour versus green taxes. Fiscal Policy and Growth, 403.

BAUMEISTER, Christiane \& KILIAN, Lutz (2016). Forty years of oil price fluctuations: Why the price of oil may still surprise us, Journal of Economic Perspectives, 30(1): 139-60.

BERG, Andy, and OSTRY, Jonathan D. (2011). Equality and efficiency. Finance \& Development, 48(3): 12-15.

BERG, A.G. \& OSTRY, J.D., 2013. Equality and efficiency: Is there a trade-off between the two?. Reducing Inequalities: A Sustainable Development Challenge, p.96.

BESLEY, Timothy \& GHATAK, Maitreesh (2010), Property rights and economic development, In Handbook of Development Economics, edited by Dani Rodrik \& Mark Rosenzweig, Vol.5, Amerstam: North-Holland, pp. 4525-4596. 
BESLEY, Timothy J. \& PERSSON, Torsten (2013). Taxation and development. In AUERBACH, A. J., CHETTY, R., FELDSTEIN, M., \& SAEZ, E. (Eds.). Handbook of Public Economics (Vol. 5). Newnes, pp.51-110.

BLANCHARD, Olivier, and COTTARELLI, Carlo, (2010). Ten commandments for fiscal adjustment in advanced economies. IMF Direct blog.

BLANCHFLOWER, David G. \& OSWALD, Andrew J. (2004). Well-being over time in Britain and the USA. Journal of Public Economics, 88(7-8): 1359-86.

BLANCHFLOWER, D., BELL, David N.F., MONTAGNOLI, A. \& MORO, M. (2014). The happiness tradeoff between unemployment and inflation. Journal of Money, Credit and Banking, 46(S2): 117-141.

BRUNNERMEIER, Markus K. and SANNIKOV, Yuliy (2014). A macroeconomic model with a financial sector, American Economic Review, 104(2): 379-421.

BUITER, W.H. (2003) Ten commandments for a fiscal rule in E(M)U, Oxford Review of Economic Policy, 19: 84-99.

BURNS, Sarah K., \& ZILIAK, James P. (2017). Identifying the elasticity of taxable income. Economic Journal, 127: 297-329.

CAIRNS, Robert D., and CALFUCURA, Enrique, (2012). OPEC: Market failure or power failure? Energy Policy 50: 570-80.

COLGAN, Jeff D. 2014. The emperor has no clothes: The limits of OPEC in the global oil market, International Organization, 68(3): 599-632.

CLARKE, Edward H. (1980). Demand Revelation and the Provision of Public Goods, Cambridge, Mass.: Harper \& Row, Ballinger.

COLANDER, David \& KUPERS, Roland (2014). Complexity and the Art of Public Policy, Princeton University Press.

DIENER, E., KAHNEMAN, D. \& HELLIWELL, J. (2010). International Differences in WellBeing. Oxford: Oxford University Press.

GERRITSEN, Aart (2016). Optimal taxation when people do not maximize well-being, Journal of Public Economics, 144: 122-39.

GREIF, Avner \& IYIGUN, Murat (2013). What did the old poor law really accomplish? Aredux. Institute for the Study of Labor Discussion Paper 7398. 
GROVES, Theodore (1973). Incentives in teams, Econometrica, 41:617-33.

GUILLEN-ROYO, Monica (2011). Reference group consumption and the subjective wellbeing of the poor in Peru. Journal of Economic Psychology, 259-272.

JACOBS, Bas (2013). The marginal cost of public funds is one at the optimal tax system. Erasmus University Rotterdam.

KAHNEMAN, Daniel (2011). Thinking, Fast and Slow. New York: Farrar, Strauss and Giroux.

KAPLOW, Louis (1996), The optimal supply of public goods and the distortionary cost of taxation, National Tax Journal, 49 (4), 513-533.

KAPLOW, Louis (2008). The Theory of Taxation and Public Economics, Princeton University Press.

KAPLOW, Louis \& SHAVELL, Steven (2002). Fairness Versus Welfare, Harvard University Press.

KIRMAN, Alan (2016). Complexity and economic policy: A paradigm shift or a change in perspective? A review essay on David Colander and Roland Kupers's Complexity and the Art of Public Policy, Journal of Economic Literature, 54(2): 534-72.

KNIGHT, John, SONG, Lina \& GUNATILAKA, Ramani (2009). Subjective well-being and its determinants in rural China. China Economic Review, 20(4): 635-49.

KRUGMAN, Paul R. (1987). Is free trade passe? Journal of Economic Perspectives, 1(2): 13144.

LEMAN, Christopher K., and NELSON, Robert H. (1981). Ten commandments for policy economists. Journal of Policy Analysis and Management, 1(1): 97-117.

LEVINSON, Arik (2012). Valuing public goods using happiness data: The case of air quality, Journal of Public Economics, 96(9-10): 869-880.

LINDERT, Peter H. 2004. Growing Public: Volume 1, The Story: Social Spending and Economic Growth since the Eighteenth Century. Cambridge and New York: Cambridge University Press.

LINDERT, Peter H. 2009. Growing Public: Volume 2, Further Evidence: Social Spending and Economic Growth since the Eighteenth Century. Cambridge and New York: Cambridge University Press. 
LINSSEN, Rik, VAN KEMPEN, Luuk \& KRAAYKAMP, Gerbert (2011). Subjective wellbeing in rural India: The curse of conspicuous consumption. Social Indicators Research, 101(1): 57-72, DOI: 10.1007/s11205-010-9635-2.

LIPSEY, Richard G., \& LANCASTER, Kelvin (1956), The general theory of second best, Review of Economic Studies, 24:11-32.

LIPSEY, Richard G. (2017). Generality versus context specificity: First, second and third best in theory and policy, Pacific Economic Review.

MAS-COLELL, Andeu, WHINSTON, Michael D., \& GREEN, Jerry R., (1995). Microeconomics Theory. Oxford: Oxford University Press

MEADE, James E. (1964), Efficiency, Equality, and the Ownership of Property, London: Allen \& Unwin.

MILLER, John H. (2015). A Crude Look at the Whole: The Science of Complex Systems in Business, Life, and Society. New York: Perseus Books, Basic Books.

MILANOVIĆ, Branko. (2011). More or less. Finance and Development, 48(3): 6-11.

MIRRLEES, James A. (1971), An exploration in the theory of optimum income taxation, Review of Economic Studies, 38:175-208.

MOKYR, Joel (2014). A flourishing economist: A review essay on Edmund Phelps's mass flourishing: How grassroots innovation created jobs, challenge, and change. Journal of Economic Literature, 52(1): 189-196.

MUELLER, Dennis (2009). Reason, Religion, and Democracy, Cambridge University Press.

NG, Yew-Kwang (1977), Towards a theory of third best, Public Finance/Finances Publiques, 32: $1-15$.

NG, Yew-Kwang (1984), Quasi-Pareto social improvements, American Economic Review, December 1984, 74(5):1033-1050.

NG, Yew-Kwang (1987), Diamonds are a government's best friend: Burden-free taxes on goods valued for their values”, American Economic Review, 77: 186-191.

NG, Yew-Kwang (1990), Welfarism and utilitarianism: A rehabilitation, Utilitas, 2(2): 171-193.

NG, Yew-Kwang (2000). Effciency, Equality, and Public Policy: With a Case for Higher Public Spending. Macmillan, Basingstoke, Hampshire.

NG, Yew-Kwang (2003). From preference to happiness: Towards a more complete welfare economics. Social Choice and Welfare, 20(2): 307-350. 
NG, Yew-Kwang (2004). Welfare Economics: Towards a More Complete Analysis. London: Palgrave/ Macmillan.

NG, Yew-Kwang (2008). Environmentally responsible happy nation index. Social Indicators Research, 85: 425-446.

NG, Yew-Kwang (2009). Increasing Returns and Economic Efficiency, Palgrave/Macmillan, U.K.

NG, Yew-Kwang (2013). The Road to Happiness, Shanghai: Fudan University Press. (In Chinese.)

NG, Yew-Kwang (2014). Why is finance important? Some thoughts on post-crisis economics, Singapore Economic Review, Vol. 59, No. 5.

NG, Yew-Kwang (2015). Welfare economics, In: James D. Wright (editor-in-chief), International Encyclopedia of the Social \& Behavioral Sciences, 2nd edition, 2015, Vol 25. Oxford: Elsevier. pp. 497-503.

NG, Yew-Kwang (2017). Theory of third best: How to interpret and apply? Pacific Economic Review.

NG, Yew-Kwang (forthcoming). Markets and Morals, contract signed with Cambridge University Press.

O'DONNELL, Gus (2012). Ten commandments of good policy making: A retrospective by Sir Gus O’Donnell. British Politics and Policy at LSE (2012). http://eprints.lse.ac.uk/48283/

OGILVIE, Sheilagh \& CARUS, A.W. (2014). Institutions and economic growth in historical perspective, In Handbook of Economic Growth, vol. 2, edited by Philippe Aghion and Steven N. Durlauf, pp.403-513

OKUN, Arthur M. (1975/2015), Equality and Efficiency: The Big Tradeoff, (Washington: Brookings Institution).

PIGOU, Arthur C. (1928), Public Finance (London: Macmillan).

SAMUELSON, Paul A. (1954), The pure theory of public expenditure, Review of Economics and Statistics, 36:387-9.

SEN, Amartya (2010). The Idea of Justice. London: Penguin.

SOLAR, Peter (1995). Poor relief and English economic development before the industrial revolution, Economic History Review, 48(1), 1-22.

STIGLITZ, Joseph J. (1988), Economics of the Public Sector, (New York: Norton). 
STIGLITZ, Joseph J. (2012). The Price of Inequality. How Today's Divided Society Endangers our Future, (New York, Norton).

STIGLITZ, Joseph J. (2015). How to Fix Inequality, Boston Globe.

STIGLITZ, Joseph J., SEN, Amartya, \& FITOUSS, Jean-Paul, (2009). Report by the Commission on the Measurement of Economic Performance and Social Progress. $\quad$ http://www.insee.fr/fr/publications-et-services/dossiers_web/stiglitz/doccommission/RAPPORT_anglais.pdf

THALER, Richard H. \& SUNSTEIN. Cass R. (2009). Nudge: Improving Decisions about Health, Wealth, and Happiness. New York: Penguin.

United Nations Development Programme (2015). Human Development Reports. http://hdr.undp.org/en

VICKREY, William (1961), Counterspeculation, auctions and competitive sealed tenders, Journal of Finance, 16:8-37.

YANG, Xiaokai and NG, Yew-Kwang (1993). Specialization and Economic Organization, a New Classical Microeconomic Framework. Amsterdam: North-Holland.

YILMAZ, Ensar; B.E. (2016). Market imperfections and income distribution, B. E. Journal of Economic Analysis and Policy, 16(2): 1147-67. 